\title{
Nocardia flavorosea sp. nov.
}

\author{
Jongsik Chun, ${ }^{1 \dagger} \dagger$ Chi-Nam Seong, ${ }^{2}$ Kyung Sook Bae, ${ }^{3}$ Kye-Joon Lee, ${ }^{1}$ \\ Sa-Ouk Kang, ${ }^{1}$ Michael Goodfellow ${ }^{4}$ and Yung Chil Hah'
}

Author for correspondence: Yung Chil Hah. Tel: +8228806700 . Fax: +8228884911

e-mail: hahyungc@plaza.snv.ac.kr

\footnotetext{
1 Department of

Microbiology, College of Natural Sciences and Research Center for Molecular Microbiology, Seoul National University, Seoul 151-742, Republic of Korea

2 Department of Biology, College of Natural Sciences, Sunchon National University, Sunchon 540742 , Republic of Korea

3 Genetic Resources Center, Korea Research Institute of Bioscience and Biotechnology, PO Box 115 Yusong, Taejon 305-600, Republic of Korea

4 Department of Microbiology, The Medical School, Framlington Place, Newcastle upon Tyne NE2 $4 \mathrm{HH}, \mathrm{UK}$
}

\begin{abstract}
An actinomycete strain, 'Nocardia flavorosea' JCM 3332, was found to have properties consistent with its classification in the genus Nocardia. An almost complete gene sequence of the $16 \mathrm{~S}$ rDNA of the strain was determined following cloning and sequencing of the amplified gene. The sequence was aligned with those available for nocardiae and phylogenetic trees were inferred using four tree-making algorithms. The organisms consistently formed a distinct clade with the type strain of Nocardia carnea. However, DNA relatedness experiments showed that the strain and $N$. carnea DSM $43397^{\top}$ belonged to two distinct genomic species. The organism was also distinguished from representatives of all of the validly described species of Nocardia using a combination of phenotypic properties. These genotypic and phenotypic data show that the strain merits recognition as a new species of the genus Nocardia. The name proposed for the new species is Nocardia flavorosea sp. nov. The type strain is JCM $3332^{\top}$.
\end{abstract}

Keywords: Nocardia flavorosea, classification, soil bacteria, actinomycetes

\section{INTRODUCTION}

The taxonomy of the genus Nocardia Trevisan 1889 has undergone marked revision with the application of chemotaxonomic, molecular systematic and numerical phenetic methods (Goodfellow, 1992, 1998). Indeed, the proposal to recognize actinomycetes previously classified as Nocardia pinensis as Skermania piniformis (Chun et al., 1997) leaves the genus as a homogeneous taxon for the first time in its long and chequered taxonomic history (Goodfellow, 1998; Lechevalier, 1976). The genus Nocardia encompasses eleven validly described species, forms a monophyletic clade within the evolutionary radiation occupied by mycolic acidcontaining actinomycetes (the mycolata), and has a phylogenetic depth comparable to that of other

\footnotetext{
tPresent address: Center of Marine Biotechnology, University of Maryland Biotechnology Institute, 701 East Pratt Street, Baltimore, MD 21202, USA.

Abbreviation : GYEA, glucose/yeast extract agar.

The GenBank accession number for the 16S rDNA sequence of strain JCM $3332^{\top}$ reported in this paper is $\mathbf{Z 4 6 7 5 4}$.
}

mycolata genera (Chun \& Goodfellow, 1995; Chun et al., 1996; Goodfellow, 1998).

Members of the redefined genus Nocardia (Goodfellow, 1992, 1998) produce extensively branched substrate hyphae which fragment in situ or on mechanical disruption into rod-shaped to coccoid, non-motile elements. Aerial hyphae, at times only visible microscopically, are abundant and always found. Nocardiae have: meso-diaminopimelic acid, arabinose and galactose in the cell wall (wall chemotype IV; sensu Lechevalier \& Lechevalier, 1970); muramic acid in an $\mathrm{N}$-glycolyl form; diphosphatidylglycerol, phosphatidylethanolamine, phosphatidylinositol and phosphatidylinositol mannosides as predominant phospholipids; major amounts of straightchain, unsaturated and tuberculostearic fatty acids; mycolic acids with 44-60 carbon atoms; and hexahydrogenated menaquinone with eight isoprene units where the end two are cyclized as the predominant menaquinone. The $\mathrm{G}+\mathrm{C}$ content of the DNA lies within the range $64-72 \mathrm{~mol} \%$.

The present investigation was designed to clarify the taxonomic position of a soil isolate, strain JCM $3332^{\mathrm{T}}$, 


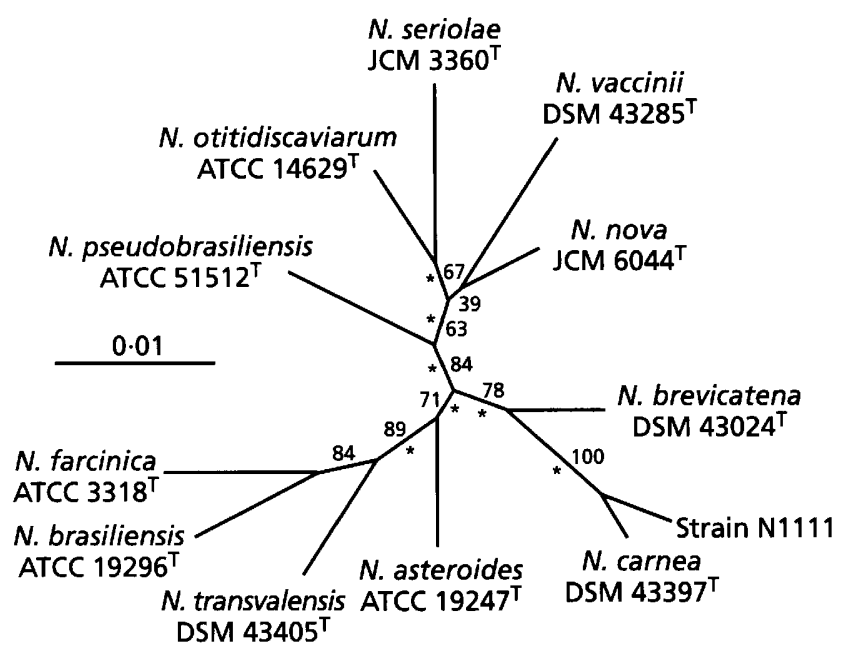

Fig. 1. Unrooted neighbour-joining tree based on 1408 unambiguously aligned nucleotide positions. Asterisks indicate the branches that were also recovered in the remaining three methods employed in this study (see text). The numbers at the nodes are the levels of bootstrap support based on neighbourjoining analyses of 1000 resampled data sets. The scale bar represents 0.01 nucleotide substitutions per position.

which had been characterized and provisionally assigned to the genus Nocardia as 'Nocardia flavorosea' by Liu et al. (1983). Genotypic and phenotypic data show that the strain should be formally recognized as a new species of the genus Nocardia for which the name Nocardia flavorosea sp. nov. is proposed.

\section{METHODS}

Bacterial strain and culture conditions. Strain JCM $3332^{\mathrm{T}}$ $\left(=\mathrm{NRRL} \mathrm{B}-16176^{\mathrm{T}}\right)$ was grown at $30^{\circ} \mathrm{C}$ for $7 \mathrm{~d}$ in shake flasks containing modified Sauton's broth (Modarska et al., 1972). Biomass for the chemotaxonomic studies was collected by centrifugation, washed twice with distilled water and freeze-dried. The strain was maintained as glycerol suspensions $(20 \%, \mathrm{v} / \mathrm{v})$ at $-20^{\circ} \mathrm{C}$.

Phenotypic characterization. The cultural and staining properties of the test strain were determined from glucose/yeast extract agar (GYEA; Jones, 1949) plates incubated at $30^{\circ} \mathrm{C}$ for $3 \mathrm{~d}$. After incubation, colonies were examined both by eye and microscopically. Unless otherwise stated, the remaining tests were read after incubation at $30{ }^{\circ} \mathrm{C}$. The degradation tests were carried out using GYEA as the basal medium and the results were read after 4 weeks following the established procedure (Boiron et al., 1993; Gordon et al., 1974). The temperature tests were read from GYEA plates incubated for 4 weeks $\left(10^{\circ} \mathrm{C}\right)$ and 2 weeks $(25$, 35,45 and $50^{\circ} \mathrm{C}$ ). The biochemical tests and acid production from sugars were carried out after Gordon et al. (1974). Utilization of organic acids was determined according to Koser (1924). Resistance to antibiotics was examined using bacitracin $(10 \mathrm{U})$, gentamicin $(10 \mu \mathrm{g})$, penicillin $(10 \mu \mathrm{g})$, streptomycin $(10 \mu \mathrm{g})$ and tobramycin $(10 \mu \mathrm{g})$ disks (Oxoid), and GYEA as basal medium. Readings were taken at 14, 21 and $28 \mathrm{~d}$. The ability to inhibit the growth of Escherichia coli HB101 was observed using an overlay technique. Multi- inoculated colonies on nutrient agar plates were inverted over $1.5 \mathrm{ml}$ chloroform for $40 \mathrm{~min}$. Killed colonies were then overlaid with $5 \mathrm{ml}$ sloppy agar $(0.7 \%, \mathrm{w} / \mathrm{v}$; Oxoid Nutrient Agar No. 2) inoculated with E. coli. Zones of inhibition were measured after $24 \mathrm{~h}$ at $30^{\circ} \mathrm{C}$.

Chemotaxonomy. Isomers of $\mathrm{A}_{2} \mathrm{pm}$ were analysed by the method of Staneck \& Roberts (1974). The small-scale method of Minnikin et al. (1984) was used to extract menaquinones from freeze-dried biomass (about $100 \mathrm{mg}$ ). Purified menaquinones were analysed using an electronimpact mass spectrometer (JEOL SX-102), as described earlier (Chun et al., 1997). Freeze-dried biomass (about 50 $\mathrm{mg}$ ) of the test strain was also degraded by acid-methanolysis (Minnikin et al., 1980) and the resultant fatty acid and mycolic acid methyl esters were purified by preparative TLC. The fatty acid methyl esters were examined using the MIDI system (Sasser, 1990), and the composition of the mycolic acid methyl esters was determined using electronimpact mass spectrometry according to Collins et al. (1982). The analysis of sugars as their alditol acetates was carried out after Saddler et al. (1991).

Determination of DNA base composition. DNA was prepared according to Chun \& Goodfellow (1995). The G+C content of the DNA was determined by the thermal denaturation method (Mandel \& Marmur, 1968).

$16 S$ rDNA sequencing. Isolation of chromosomal DNA, and PCR, cloning and sequencing of the 16S rDNA were carried out using the Taq DyeDeoxy Terminator Cycle Sequencing kit (Applied Biosystems) and an Applied Biosystems 373A DNA sequencer as described previously (Chun \& Goodfellow, 1995). The resultant 16S rDNA sequence was aligned manually against sequences of representative mycolic acid-containing actinomycetes using the AL16S program (Chun, 1995). The additional sequence data were obtained from the GenBank/EMBL databases. Phylogenetic trees were inferred using four tree-making algorithms, namely the Fitch-Margoliash (Fitch \& Margoliash, 1967), maximum-likelihood (Felsenstein, 1981), maximum-parsimony (Fitch, 1972) and neighbour-joining (Saitou \& Nei, 1987) methods. Evolutionary distance matrices for the neighbour-joining and Fitch-Margoliash methods were generated according to Jukes \& Cantor (1969). The PHYLIP package (Felsenstein, 1993) was used for all analyses. The resultant unrooted tree topology was evaluated in bootstrap analyses (Felsenstein, 1985) of the neighbour-joining method based on 1000 resamplings.

DNA-DNA hybridization. Levels of genomic relatedness between strain JCM $3332^{\mathrm{T}}$ and Nocardia carnea DSM $43397^{\mathrm{T}}$ were determined by the DNA-DNA slot-blot hybridization method (Kafatos et al., 1979). Chromosomal DNA was extracted from test strains according to Chun \& Goodfellow (1995). Duplicated aliquots containing $1 \mu \mathrm{g}$ each genomic DNA were denatured by boiling for $10 \min$ in $0.4 \mathrm{M} \mathrm{NaOH}$, transferred onto positively charged nylon membranes (Amersham) using a slot-blot apparatus (Bio-Rad), and immobilized using UV crosslinking. Prehybridization was carried out at $62^{\circ} \mathrm{C}$ for $2 \mathrm{~h}$ in hybridization buffer containing $3 \times$ SSC $(1 \times$ SSC is $0.15 \mathrm{M} \mathrm{NaCl}$ plus $0.015 \mathrm{M}$ sodium citrate), $35 \%$ formamide, $1 \%$ blocking agent (Boehringer Mannheim) and $100 \mu \mathrm{g}$ denatured and sheared salmon sperm DNA (Sigma) per ml. The probes were labelled with digoxigenin using a Random Prime Labelling kit (Boehringer Mannheim) and added $(10 \mathrm{ng} / \mathrm{ml})$ to fresh hybridization solution containing the loaded membranes. Hybridization was performed at $62^{\circ} \mathrm{C}$ for $20 \mathrm{~h}$ and 
hybridized membranes were washed according to the manufacturer's instruction. Chemoluminescence was detected using a Boehringer Mannheim detection kit and exposed to Hyperfilm (Amersham). The chemoluminescent intensity of each blot was quantified using a densitometer (Molecular Dynamics). After detection, the membrane was washed for reprobing according to the manufacturer's instructions (Boehringer Mannheim). The signal produced by selfhybridization of the probe with homologous target DNA was taken as $100 \%$ and the percentage homology values were calculated for the duplicated slots.

\section{RESULTS AND DISCUSSION}

An almost complete $16 \mathrm{~S}$ rDNA sequence (1472 nt) was obtained for the test strain. When this sequence was compared with those of representative actinomycetes, it was apparent that strain JCM $3332^{\mathrm{T}}$ belonged to the genus Nocardia (data not shown). This assignment is also supported by the chemotaxonomic and morphological data. Strain JCM $3332^{\mathrm{T}}$ forms a substrate mycelium which undergoes fragmentation. It contains: meso-diaminopimelic acid as the wall diamino acid; arabinose and galactose as major wall sugars; major amounts of saturated, monounsaturated and tuberculostearic fatty acids; mycolic acids with 50-56 carbon atoms; hexahydrogenated menaquinones with eight isoprene units where the end two are cyclized [i.e. major peak at $m / z 720$ (the molecular ion) and a significant peak at $\mathrm{m} / \mathrm{z} 584$ (molecular ion minus a terminal cyclized two isoprene moieties)] as the major isoprenologue; and DNA with a $\mathrm{G}+\mathrm{C}$ content of 69 mol\%. All of these properties are consistent with classification of the strain in the genus Nocardia (Chun \& Goodfellow, 1995; Chun et al., 1997; Goodfellow, 1998).

The unrooted evolutionary tree (Fig. 1) shows that strain JCM $3332^{\mathrm{T}}$ forms a monophyletic clade with $N$. carnea. This relationship was highlighted in the analyses based on all four tree-making algorithms, by the high nucleotide similarity value $(99.2 \%$ or 12 differences out of $1472 \mathrm{nt}$ positions) and the $100 \%$ bootstrap value recorded with the neighbour-joining method. However, it is clear from the DNA-DNA relatedness study that strain $\mathrm{JCM} 3332^{\mathrm{T}}$ and $N$. carnea DSM $43397^{\mathrm{T}}$ belong to separate genomic species. The mean DNA relatedness value was $5 \%$ when $N$. carnea DSM $43397^{\mathrm{T}}$ was used as the probe and $2 \%$ in the corresponding experiment where strain $\mathrm{JCM} 3332^{\mathrm{T}}$ was labelled. It is also apparent that strain JCM $3332^{\mathrm{T}}$ can be distinguished from representatives of all of the validly described species of the genus Nocardia, including $N$. carnea, using a combination of phenotypic properties (Table 1). These observations are in good

Table 1. Phenotypic characteristics that differentiate strain JCM $3332^{\top}$ from 11 other nocardiae

Data obtained from Boiron et al. (1993), Goodfellow (1992, 1998), Goodfellow \& Lechevalier (1989), Kudo et al. (1988) and Ruimy et al. (1996). Symbols:,$+ \geqslant 90 \%$ strains are positive; $-\geqslant 90 \%$ strains are negative; v, variable; ND, not determined. 1, Strain JCM 3332 $; 2$, Nocardia asteroides; 3, Nocardia brasiliensis; 4 , Nocardia brevicatena ; 5, Nocardia carnea; 6 , Nocardia farcinica; 7, Nocardia nova ; 8, Nocardia otitidiscaviarum; 9, Nocardia pseudobrasiliensis; 10, Nocardia seriolae; 11 , Nocardia transvalensis; and 12, Nocardia vaccinii.

\begin{tabular}{|c|c|c|c|c|c|c|c|c|c|c|c|c|}
\hline Characteristic & 1 & 2 & 3 & 4 & 5 & 6 & 7 & 8 & 9 & 10 & 11 & 12 \\
\hline \multicolumn{13}{|l|}{ Acid production from: } \\
\hline Adonitol & - & - & - & - & - & - & - & - & ND & - & + & - \\
\hline Arabinose & - & - & - & - & - & - & - & $\mathrm{v}$ & - & - & - & + \\
\hline Glucose & - & + & + & - & + & + & + & + & + & + & + & + \\
\hline Mannitol & - & - & + & - & + & - & ND & $\mathrm{V}$ & + & - & $\mathrm{v}$ & + \\
\hline Rhamnose & - & - & - & + & - & + & - & - & ND & - & - & + \\
\hline Sorbitol & - & - & - & - & + & - & - & - & $\mathrm{ND}$ & - & - & - \\
\hline \multicolumn{13}{|l|}{ Biochemical tests: } \\
\hline Aesculin hydrolysis & - & + & + & + & + & + & ND & + & ND & + & + & + \\
\hline Nitrate reductase & - & + & + & - & + & + & + & + & - & ND & + & + \\
\hline Urease & - & + & + & - & - & + & + & + & + & - & + & + \\
\hline \multicolumn{13}{|l|}{ Decomposition of: } \\
\hline Adenine & - & - & - & - & - & - & - & - & + & - & $\mathrm{v}$ & - \\
\hline Casein & - & - & + & - & - & - & - & - & + & - & - & 一 \\
\hline Elastin & - & - & + & - & - & - & - & - & $\mathrm{v}$ & - & - & - \\
\hline Hypoxanthine & - & - & + & - & - & - & - & + & + & - & + & - \\
\hline Testosterone & + & + & + & + & + & + & + & - & - & $\mathrm{v}$ & - & - \\
\hline Tyrosine & - & - & + & - & - & - & - & - & + & - & - & - \\
\hline Uric acid & + & - & - & ND & - & - & - & + & + & $\mathrm{v}$ & + & - \\
\hline Xanthine & - & - & - & - & - & - & - & + & - & - & - & - \\
\hline Growth at $45^{\circ} \mathrm{C}$ & + & - & + & - & - & + & - & + & ND & - & ND & - \\
\hline Utilization of citrate & - & + & + & - & - & - & - & - & ND & + & ND & - \\
\hline
\end{tabular}


agreement with the results of a numerical phenetic survey which showed that 'Nocardia flavorosea' JCM $3332^{\mathrm{T}}$ formed a single-membered cluster (Yano et al., 1990).

It is clear from the genotypic and phenotypic data that strain JCM $3332^{\mathrm{T}}$ merits species status in the genus Nocardia. It is, therefore, proposed that the organism be classified in the genus Nocardia as Nocardia flavorosea sp. nov.

\section{Description of Nocardia flavorosea sp. nov.}

Nocardia flavorosea (fla.vo.ro'se.a. L. adj. flavus yellow; L. fem. adj. rosea rose-coloured; M.L. adj. flavorosea yellow rose).

Aerobic, Gram-positive, catalase-positive, partially acid-alcohol-fast, non-motile actinomycetes which form an extensively branched substrate mycelium which fragments in situ into rod-shaped to coccoid elements. The orange substrate mycelium carries white to pinkish aerial hyphae. Colony elevation is convex to irregular and colony margins are filamentous. Diffusible pigments are not formed. Growth occurs between 25 and $50{ }^{\circ} \mathrm{C}$, but not at $10^{\circ} \mathrm{C}$. Starch is degraded but not adenine, casein, gelatin, tyrosine or xanthine. Allantoin, hippuric acid and urea are not hydrolysed and nitrate reductase and phenylalanine deaminase are not produced. Acid is formed from dulcitol but not from adonitol, L-arabinose, cellobiose, dextrin, D-fructose, D-galactose, D-glucose, meso-inositol, D-lactose, D-maltose, D-mannitol, D-mannose, D-melezitose, D-melibiose, raffinose, L-rhamnose, salicin, D-sorbitol, sucrose, D-trehalose, xylitol or Dxylose. Propionate, pyruvate and succinate are used as sole carbon sources for energy and growth, but benzoate, citrate, gluconate, lactate, mucate and oxalate are not. The organism is resistant to bacitracin and penicillin, but sensitive to gentamicin, streptomycin and tobramycin. Antibiosis activity is evident against E. coli.

The organism contains major amounts of mycolic acids with 50-56 carbon atoms and 2-4 double bonds $\left(\mathrm{C}_{50: 3}, \mathrm{C}_{52: 2}, \mathrm{C}_{52: 3}, \mathrm{C}_{52: 4}, \mathrm{C}_{54: 2}\right.$ and $\left.\mathrm{C}_{56: 3}\right)$. The major cellular fatty acids are hexadecanoic $(29 \%$ of total fatty acids), octadecenoic (23\%), 10-methyloctadecanic (tuberculostearic, 17\%) and hexadecenoic $(9 \%)$ acids. The remaining chemical properties of the organism were given earlier. The $\mathrm{G}+\mathrm{C}$ content of the DNA of strain JCM $3332^{\mathrm{T}}$ is $69 \mathrm{~mol} \%$, as determined by the thermal denaturation method. The type strain is JCM $3332^{\mathrm{T}}(=$ NRRL B-16176 $)$. This strain was isolated from soil collected in Yunnan Province, China.

\section{ACKNOWLEDGEMENTS}

Part of this work was supported by a Korean Science and Engineering Council (KOSEF) grant to the Research Center for Molecular Microbiology (RCMM) and the British Council Academic Link Scheme (Seoul, Korea). The authors are indebted to Dr Ken Suzuki (JCM) for the gift of the test strain.

\section{REFERENCES}

Boiron, P., Provost, F. \& Duport, B. (1993). Laboratory Methods for the Diagnosis of Nocardiosis. Paris: Institut Pasteur.

Chun, J. (1995). Computer-assisted classification and identification of actinomycetes. PhD thesis, University of Newcastle upon Tyne.

Chun, J. \& Goodfellow, M. (1995). A phylogenetic analysis of the genus Nocardia with $16 \mathrm{~S}$ rRNA gene sequences. Int $J$ Syst Bacteriol 45, 240-245.

Chun, J., Kang, S.-O., Hah, Y. C. \& Goodfellow, M. (1996). Phylogeny of mycolic acid-containing actinomycetes. $J$ Ind Microbiol 17, 205-213.

Chun, J., Blackall, L. L., Kang, S.-O., Hah, Y. C. \& Goodfellow, M. (1997). A proposal to reclassify Nocardia pinensis Blackall et al. as Skermania piniformis gen. nov., comb. nov. Int $J$ Syst Bacteriol 47, 127-131.

Collins, M. D., Goodfellow, M. \& Minnikin, D. E. (1982). A survey of the structures of mycolic acid in Corynebacterium and related taxa. J Gen Microbiol 128, 129-149.

Felsenstein, J. (1981). Evolutionary trees from DNA sequences: a maximum likelihood approach. J Mol Evol 17, 368-376.

Felsenstein, J. (1985). Confidence limits on phylogenies: an approach using the bootstrap. Evolution 39, 783-791.

Felsenstein, J. (1993). PHYLIP (phylogenetic inference package), version 3.5c. Department of Genetics, University of Washington, Seattle, USA.

Fitch, W. M. (1972). Toward defining the course of evolution: minimum change for a specific tree topology. Syst Zool 20 , 406-416.

Fitch, W. M. \& Margoliash, E. (1967). Construction of phylogenetic trees: a method based on mutation distances as estimated from cytochrome $c$ sequences is of general applicability. Science 155, 279-284.

Goodfellow, M. (1992). The family Nocardiaceae. In The Prokaryotes, 2nd edn, pp. 1188-1213. Edited by A. Balows, H. G. Trüper, M. Dworkin, W. Harder \& K.-H. Schleifer. New York: Springer.

Goodfellow, M. (1998). The actinomycetes: Nocardia and related genera. In Topley and Wilson's Microbiology and Microbial Infections, 9th edn, vol. 2, Systematic Bacteriology. Edited by A. Balows \& B. I. Duerden. London: Edward Arnold (in press).

Goodfellow, M. \& Lechevalier, M. P. (1989). Genus Nocardia Trevisan 1889, $9^{\mathrm{AL}}$. In Bergey's Manual of Systematic Bacteriology, pp. 2350-2361. Edited by S. T. Williams, M. E. Sharpe \& J. G. Holt. Baltimore: Williams \& Wilkins.

Gordon, R. E., Barnett, D. A., Handerhan, J. E. \& Pang, C. H. N. (1974). Nocardia coeliaca, Nocardia autotrophica, and the Nocardin strain. Int J Syst Bacteriol 24, 54-63.

Jones, K. L. (1949). Fresh isolates of actinomycetes in which the presence of sporogenous aerial mycelia is a fluctuating characteristic. $J$ Bacteriol 57, 141-145.

Jukes, T. H. \& Cantor, C. R. (1969). Evolution of protein molecules. In Mammalian Protein Metabolism, pp. 21-132. Edited by H. N. Munro. New York: Academic Press.

Kafatos, F. C., Jones, C. W. \& Efsratiadis, A. (1979). Determination of nucleic acid sequence homologies and relative concentrations by a dot hybridization procedure. Nucleic Acids Res 7, 1541-1545. 
Koser, S. A. (1924). Correlation of citrate utilization by members of the colon-aerogenes groups with other differential characteristics and with habitat. $J$ Bacteriol 9, 59-77.

Kudo, T., Hatai, K. \& Seino, A. (1988). Nocardia seriolae sp. nov. causing nocardiosis of cultured fish. Int J Syst Bacteriol 38, 173-178.

Lechevalier, M. P. (1976). The taxonomy of the genus Nocardia: some light at the end of tunnel? In The Biology of the Nocardiae, pp. 1-38. Edited by M. Goodfellow, G. H. Brownell \& J. A. Serrano. London: Academic Press.

Lechevalier, M. P. \& Lechevalier, H. A. (1970). Chemical composition as a criterion in the classification of aerobic actinomycetes. Int J Syst Bacteriol 20, 435-443.

Liu, Z., Ruan, J. S. \& Yan, X. C. (1983). The new species of Nocardia. Acta Microbiol Sinica 23, 298-304 (in Chinese).

Mandel, M. \& Marmur, J. (1968). Use of ultraviolet absorbance temperature profile for determining the guanine plus cytosine content of DNA. Methods Enzymol 12B, 195-206.

Minnikin, D. E., Hutchinson, I. G., Caldicott, A. B. \& Goodfellow, M. (1980). Thin-layer chromatography of methanolysates of mycolic acid-containing bacteria. $J$ Chromatogr 188, 221-233.

Minnikin, D. E., O’Donnell, A. G., Goodfellow, M., Alderson, G., Athalye, M., Schaal, A. \& Parlett, J. H. (1984). An integrated procedure for the extraction of isoprenoid quinones and polar lipids. J Microbiol Methods 2, 233-241.
Modarska, H., Mordarski, M. \& Goodfellow, M. (1972). Chemotaxonomic characters and classification of some nocardioform bacteria. J Gen Microbiol 71, 77-86.

Ruimy, R., Riegel, P., Carlotti, A., Boiron, P., Bernardin, G., Monteil, H., Wallace, R. J., Jr \& Christen, R. (1996). Nocardia pseudobrasiliensis sp. nov., a new species of Nocardia which groups bacterial strains previously identified as Nocardia brasiliensis and associated with invasive diseases. Int $J$ Syst Bacteriol 46, 259-264.

Saddler, G. S., Tavecchia, P., Lociuro, S., Zanol, M., Colombo, L. \& Selva, E. (1991). Analysis of madurose and other actinomycete whole cell sugars by gas chromatography. $J$ Microbiol Methods 14, 185-191.

Saitou, N. \& Nei, M. (1987). The neighbor-joining method: a new method for constructing phylogenetic trees. Mol Biol Evol 4, $406-425$.

Sasser, M. (1990). Identification of Bacteria by Gas Chromatography of Cellular Fatty Acids. Technical Note 101. Newark, DE: Microbial ID.

Staneck, J. L. \& Roberts, G. D. (1974). Simplified approach to identification of aerobic actinomycetes by thin-layer chromatography. Appl Microbiol 28, 226-231.

Trevisan, v. (1889). Generiele Specie delle Batteriacee. Milan: Zanaboni \& Gabuzzi.

Yano, I., Imaeda, T. \& Tsukamura, M. (1990). Characterization of Nocardia nova. Int J Syst Bacteriol 40, 170-174. 